\title{
THE EFFECT OF PARAGENETIC FACTORS ON BODY DEVELOPMENT OF SIMMENTAL BULL DAMS **
}

\author{
V. Pantelić $^{1 *}$, Z. Skalicki ${ }^{2}$, V. Bogdanović ${ }^{2}$, N. Delić ${ }^{1}$, S. Pejčić ${ }^{1}$ \\ ${ }^{1}$ Institute for Animal Husbandry, Belgrade-Zemun, 11080 Zemun \\ ${ }^{2}$ Faculty of Agriculture, Belgrade \\ * Corresponding author:Vlada Pantelić, e-mail: vladapantelic.izs@gmail.com \\ ** Originalni naučni rad-Original scientific paper
}

\begin{abstract}
Body development and type are very important indices of production ability of cows, their capacity to consume sufficient quantity of food, produce technologically high quality milk, reduce the energy consumption in production of milk, remain in exploitation as long as possible and give more progeny. This research included 278 cows of Simmental breed selected into the category of bull dams on the territory of Republic of Serbia.

By application of method of least squares following average values of exterior measures were obtained: height to withers $136,04 \mathrm{~cm}$; carcass length $165,81 \mathrm{~cm}$; breast depth $73,61 \mathrm{~cm}$; breast girth $201,12 \mathrm{~cm}$; body mass 695,29 $\mathrm{kg}$. Regions influenced statistically highly significantly all investigated exterior traits $(\mathrm{P}<0,01)$. Year of measuring had no statistically significant effect $(\mathrm{P}>0,05)$ on body development of Simmental bull dams. Obtained values were considerably uniform without any greater oscillations.
\end{abstract}

Key words: Simmental breed, bull dams, exterior, paragenetic factors

\section{Introduction and literature review}

There is certain relation between body development of head of cattle and milk production capacity. However, functionality manifested in milk production can not be defined by exterior of cows e.g. their body development. Therefore, capacity of cows for milk production can be precisely determined only by direct measuring of production.

Nenadović et al. (1987) have carried out investigation of milk production on PD »Krivaja« and at the same time also body measuring of 203 Simmental cows and established following average values: height to withers $134 \mathrm{~cm}$, breast girth $212 \mathrm{~cm}$ and body mass $704 \mathrm{~kg}$. In the monograph »Simmental cattle in Serbia«, Romčević (1999) stated following exterior 
measures of Simmental bull dams in years 1995 and 1996: height to withers in both years was the same $136 \mathrm{~cm}$, breast girth 199 and $202 \mathrm{~cm}$, and body mass 697 and $692 \mathrm{~kg}$.

Institute of science application in agriculture (2001), in their annual report on executed livestock selection measures in Serbia in year 2000 published following data on average exterior measures of 565 selected Simmental bull dams: height to withers $136 \mathrm{~cm}$, breast depth $74 \mathrm{~cm}$, carcass length $169 \mathrm{~cm}$, breast girth $199 \mathrm{~cm}$, and body mass $666 \mathrm{~kg}$.

In annual expert report on executed coordination activities in 2007, Institute for Animal Husbandry (2008) established following average values of exterior measures in 339 selected Simmental bull dams: height to withers $138,96 \mathrm{~cm}$, breast depth $76,31 \mathrm{~cm}$, carcass length $170,09 \mathrm{~cm}$, breast girth 197,38 $\mathrm{cm}$, and body mass $687,58 \mathrm{~kg}$.

Breeding region can be major environment factor influencing the body development of the head of cattle. The effect of breeding region includes many factors which complement each other, but most important is the nutrition (Pantelic 2004). In the research related to variability of the linear evaluation of the type, Pantelic et al. (2007) established highly significant effect of breeding region on evaluation of type based on evaluation of the height to withers, carcass length, breast depth and width of hip and pelvis. The effect of year of measuring was statistically significant $(\mathrm{P}<0,05)$.

\section{Material and methods}

This research included 278 cows of Simmental breed selected categorized as bull dams on the territory of Republic of Serbia. Cows were selected into the herd of bull dams after completion of the first lactation, e.g. based on subsequent lactations. Distribution of bull dams was done according to 7 regions, i.e. breeding regions and 9 groups according to the year of measuring and evaluation.

Breeding regions and number of selected bull dams in these regions were following:

1. Belgrade (municipality of Mladenovac) -22

2. Podunavlje region (municipality of Smederevska Palanka) -88

3. Braničevo region (municipality of Požarevac) -41

4. Timok region (municipality of Zaječar) - 24

5. Kolubara region (municipality of Valjevo) -55

6. Pomoravlje-Rasina region (municipalities of Jagodina, Kraljevo and Kruševac)-32

7. Zlatibor region (municipality of Užice) - 16 
Investigations included following exterior measures: height to withers, breast depth, breast girth and body mass. Analysis of the effect of paragenetic factors on investigated linear type evaluations was one using method of least squares, fixed model:

Where:

$$
\mathrm{Y}_{i j l}=\mu+\mathrm{R}_{i}+\mathrm{G}_{j}+\mathrm{e}_{i j l}
$$

$\mathrm{Y}_{i j l} \quad=$ Demonstration of investigated trait in $l$ cow, which produced in $i$ region, measured in $j$ year

$\mu \quad=$ general average

$\mathrm{R}_{i} \quad=$ fixed effect of $i$ region

$\mathrm{G}_{j} \quad=$ fixed effect of $j$ year of measuring

$\mathrm{e}_{i j l} \quad=$ random error

\section{Results and discussion}

By application of method of least squares average values of exterior measures were obtained for Simmental bull dams: height to withers 136,04 cm; carcass length $165,81 \mathrm{~cm}$; breast depth $73,61 \mathrm{~cm}$; breast girth $201,12 \mathrm{~cm}$; body mass $695,29 \mathrm{~kg}$. Visual evaluation of the body development and recognition of cow characteristics which are preliminary milk yielding indicators and partially also indicators of longevity and reproduction abilities of the heads of cattle, which is very important from the aspect of economical efficiency of milk production (Pantelić et al. 2007).

Regions had statistically significant effect on investigated exterior traits $(\mathrm{P}<0,01)$. The tallest cows were measured on the territory of municipality of Mladenovac 138,22 cm, whereas the smallest cows were measured on the territory of municipality of $134,31 \mathrm{~cm}$. Variation interval of carcass length was from 163,10 cm (Podunavlje region) to $170,57 \mathrm{~cm}$ (Belgrade region). Breeding region had highly significant effect on breast depth, where variation interval established was from $70,28 \mathrm{~cm}$ in Podunavlje region to $77,37 \mathrm{~cm}$ in Pomoravlje-Rasina region. The highest value of breast girth was determined in bull dams from the territory of municipality of Požarevac 207,52 cm, and the lowest heads from the territory of municipality of Smederevska Palanka 197,12 $\mathrm{cm}$. The effect of region was highly significant also on body mass The greatest body mass was established in heads reared Braničevo region 757,72 $\mathrm{kg}$ and the lowest in Pomoravlje-Rasina region 672,47 kg. 
Table 1. General average, mean values of least squares and their errors, and significance of the effect of breeding region on exterior measures

\begin{tabular}{|c|c|c|c|c|c|c|c|c|c|c|}
\hline Regions & $\begin{array}{l}\text { Height } \\
\text { to } \\
\text { withers }\end{array}$ & Slsm & $\begin{array}{l}\text { Carcass } \\
\text { length }\end{array}$ & Slsm & $\begin{array}{l}\text { Breast } \\
\text { depth }\end{array}$ & Slsm & $\begin{array}{c}\text { Breast } \\
\text { girth }\end{array}$ & Slsm & $\begin{array}{l}\text { Body } \\
\text { mass }\end{array}$ & Slsm \\
\hline $\begin{array}{l}\text { General } \\
\text { average }\end{array}$ & \multicolumn{2}{|c|}{136.04} & \multicolumn{2}{|c|}{165.81} & \multicolumn{2}{|c|}{73.61} & \multicolumn{2}{|c|}{201.12} & \multicolumn{2}{|c|}{695.29} \\
\hline 1. & 138.22 & 0.43 & 170.57 & 1.39 & 73.27 & 0.81 & 205.79 & 1.82 & 711.87 & 14.87 \\
\hline 2. & 135.39 & 0.31 & 163.1 & 0.97 & 70.28 & 0.57 & 197.12 & 1.26 & 678.57 & 10.51 \\
\hline 3. & 136.71 & 0.34 & 165 & 1.07 & 74.74 & 0.63 & 207.52 & 1.46 & 757.72 & 10.7 \\
\hline 4. & 135.84 & 0.45 & 163.95 & 1.41 & 72.61 & 0.83 & 201.26 & 1.83 & 681.69 & 14.43 \\
\hline 5. & 136.41 & 0.43 & 165.21 & 1.34 & 74.04 & 0.78 & 200.2 & 1.71 & 678.94 & 9.28 \\
\hline 6. & 135.4 & 0.42 & 166.16 & 1.54 & 77.37 & 0.77 & 197.8 & 1.69 & 672.47 & 12.76 \\
\hline 7. & 134.31 & 0.55 & 166.68 & 1.72 & 72.95 & 1.01 & 198.14 & 2.21 & 685.8 & 18.17 \\
\hline F-test & \multicolumn{2}{|c|}{ ftab $=8,821 * *$} & \multicolumn{2}{|c|}{ ftab $=4,283^{* * *}$} & \multicolumn{2}{|c|}{ ftab $=12,632 * *$} & \multicolumn{2}{|c|}{$\mathrm{ftab}=8,716^{* *}$} & \multicolumn{2}{|c|}{ ftab $=7,454 * *$} \\
\hline
\end{tabular}

Identical results in regard to height to withers and breast depth are presented by the Institute of science application in agriculture (2001), Pantelic et al. (2006) and Romčević (1999). Slightly lower values are presented in the research by Nenadović et al. (1987), and higher values in report by Institute for Animal Husbandry (2008). Breeding objective in Switzerland for Simmental cattle breed, except milk and meat production, includes also certain requirements in relation to body measures (Germann, E. and Pradervand, J.M 2001). Breeding objective is that cows have height to withers from 138 to 146 $\mathrm{cm}$, with body mass from $650-800 \mathrm{~kg}$. Slightly higher values in regard to carcass length can be found in the annual report "Selection of livestock in Serbia« by the Institute of Science Application in Agriculture (2001). Very close values for body mass were reported by Romčević (1999).

Year of measuring had no statistically significant effect $(\mathrm{P}>0,05)$ on body development of Simmental bull dams. Obtained values were uniform, without any greater oscillations.

Body development and type are very important indices of production ability of cows, their capacity to consume sufficient quantity of food, produce technologically high quality milk, reduce the energy consumption in production of milk, remain in exploitation as long as possible and give more progeny (Pantelić et al. 2005). 
Table 2. General average, mean values of least squares and their errors, and significance of the effect of year of measuring on exterior measures

\begin{tabular}{|c|c|c|c|c|c|c|c|c|}
\hline Year & $\begin{array}{l}\text { Height } \\
\text { to } \\
\text { withers }\end{array}$ & Slsm & $\begin{array}{c}\text { Carcass } \\
\text { length }\end{array}$ & Slsm & $\begin{array}{l}\text { Breast } \\
\text { depth }\end{array}$ & Slsm & $\begin{array}{l}\text { Breast } \\
\text { girth }\end{array}$ & Slsm \\
\hline $\begin{array}{l}\text { General } \\
\text { average }\end{array}$ & \multicolumn{2}{|c|}{136.04} & \multicolumn{2}{|c|}{165.81} & \multicolumn{2}{|c|}{73.61} & \multicolumn{2}{|c|}{201.12} \\
\hline 1. & 134.89 & 0.83 & 165.05 & 2.57 & 72.45 & 1.52 & 200.13 & 3.31 \\
\hline 2. & 136.19 & 0.72 & 164.49 & 2.24 & 75.47 & 1.32 & 200.72 & 2.88 \\
\hline 3. & 135.85 & 0.53 & 165.13 & 1.65 & 73.17 & 0.97 & 199.09 & 2.19 \\
\hline 4. & 135.79 & 0.66 & 164.42 & 2.03 & 74.28 & 1.2 & 205.79 & 2.61 \\
\hline 5. & 136.07 & 0.48 & 165.32 & 1.49 & 72.47 & 0.88 & 199.02 & 1.95 \\
\hline 6. & 136.05 & 0.38 & 165.64 & 1.16 & 72.55 & 0.69 & 198.4 & 1.5 \\
\hline 7. & 136.75 & 0.27 & 167.12 & 0.89 & 74.19 & 0.5 & 200.73 & 1.12 \\
\hline 8. & 136.33 & 0.25 & 168.76 & 0.81 & 73.81 & 0.47 & 201.25 & 1.03 \\
\hline 9. & 136.44 & 0.37 & 166.37 & 1.19 & 74.09 & 0.68 & 204.95 & 1.49 \\
\hline F-test & \multicolumn{2}{|c|}{$\mathrm{ftab}=1,024 \mathrm{~ns}$} & \multicolumn{2}{|c|}{$\mathrm{ftab}=1,493 \mathrm{~ns}$} & \multicolumn{2}{|c|}{$\mathrm{ftab}=1,236 \mathrm{~ns}$} & \multicolumn{2}{|c|}{$\mathrm{ftab}=1,834 \mathrm{~ns}$} \\
\hline
\end{tabular}

N.S - P >0.05; * - P < 0.05; ** - P<0.01

\section{Conclusion}

Evaluation of the exterior is executed based on knowledge of body development and function of certain organs, as well as most important relations between certain parts of the body. Phenotype correlation between form and production characteristics are positive but relatively low, therefore it is not possible to carry out selection in production sense based on exterior appearance of heads of cattle. Considering the exterior of progeny and their adequate selection, it is possible to reduce significantly the possibility of transfer of negative traits which can be carried by parents as recessive, and which can be spread very quickly in the population by wide use of practice of artificial insemination. Also, exterior traits related to secondary characteristics such as longevity and calving ease have increasingly important role in breedingselection programs in cattle production.

By application of the method of least squares the following average values of exterior measures in Simmental bull dams: height to withers 136,04 $\mathrm{cm}$; carcass length $165,81 \mathrm{~cm}$; breast depth $73,61 \mathrm{~cm}$; breast girth $201,12 \mathrm{~cm}$; body mass $695,29 \mathrm{~kg}$. Regions had statistically significant effect on all 
investigated exterior traits $(\mathrm{P}<0,01)$. Year of measuring had no statistically significant effect $(\mathrm{P}>0,05)$ on body development of Simmental bull dams. Obtained values were uniform, without any greater oscillations.

\title{
UTICAJ PARAGENETSKIH FAKTORA NA TELESNU RAZVIJENOST BIKOVSKIH MAJKI SIMENTALSKE RASE
}

\author{
V. Pantelić, Z. Skalicki, V. Bogdanović, N. Delić, S. Pejčić
}

\section{Rezime}

Telesna razvijenost i tip su veoma važni pokazatelji proizvodnih sposobnosti krava, njihovih mogućnosti da konzumiraju dovoljne količine hrane, daju tehnološki kvalitetno mleko, smanje utrošak energije u proizvodnji i što duže ostanu u proizvodnji i daju veći broj potomaka. Ovim istraživanjem je obuhvaćeno 278 krava simentalske rase odabrane u kategoriju bikovskih majki na području Republike Srbije.

Primenom metoda najmanjih kvadrata dobijene su prosečne vrednosti eksterijernih mera: visina grebena $136,04 \mathrm{~cm}$; dužina trupa $165,81 \mathrm{~cm}$; dubina grudi $73,61 \mathrm{~cm}$; obim grudi $201,12 \mathrm{~cm}$; telesna masa $695,29 \mathrm{~kg}$. Regioni su statistički vrlo značajno uticali na sve ispitivane eksterijerne osobine $(\mathrm{P}<0,01)$. Godina merenja nije statistički značajno uticala $(\mathrm{P}>0,05)$ na telesnu razvijenost bikovskih majki simentalske rase. Dobijene vrednosti bile su dosta ujednačene bez nekih većih oscilacija.

Ključne reči: simentalska rasa, bikovske majke, eksterijer, paragenetski uticaji.

\section{References}

GERMANN, E., PRADERVAND, J.M. (2001): Protokoll der 110. Delegiertenversammlung vom 12. Dezember 2000 in Bern. Schweizer Fleckvien Nr.2 (3-22).

INSTITUT ZA PRIMENU NAUKE U POLJOPRIVREDI (2001): Selekcija stoke u Srbiji za 2000. godinu, Beograd.

INSTITUT ZA STOČARSTVO (2008): Stručni izveštaj i rezultati obavljenih poslova koordinacije u 2007. godini, Beograd. 
NENADOVIĆ, M., ILIĆ, V., MIKLOŠ, J., FRANCUSKI, A. (1987): Telesne mere i mlečnost simentalskih krava. Stočarstvo, 7-8.

PANTELIĆ, V., PETROVIĆ, M.M., STOJIĆ, P (2005): Uputstvo za linearno ocenjivanje tipa i kondicije goveda. Institut za stočarstvo, Beograd-Zemun.

PANTELIĆ, V., SKALICKI Z., PETROVIĆ, M.M., LATINOVIĆ, D., ALEKSIĆ, S., MIŠČEVIĆ, B., DUŠICA OSTOJIĆ (2007): Linearno ocenjivanje bikovskih majki simentalske rase. Savremena poljoprivreda 1-2, p. 49-53.

PANTELIĆ, V., SKALICKI Z., PETROVIĆ, M.M.,ALEKSIĆ, S., MIŠČEVIĆ,B., D. OSTOJIĆ (2006): Telesna razvijenost bikovskih majki simentalske rase. Biotehnologija u stočarstvu 22 (3-4), p. 23-32.

PANTELIĆ, V., SKALICKI, Z., PETROVIĆ, M. M. , ALEKSIĆ, S. , MIŠČEVIĆ, B., D. OSTOJIĆ-ANDRIĆ (2007): Variability of linearly evaluated traits of type of Simmental bull dams, 2nd International Congress on Animal Husbandry: New perspectives and Challenges of Sustainable Livestock Farming, Belgrade, Sopot, 3.-5.10. 2007, Biotechnology in Animal Husbandry, Book 1, 201-209.

PANTELIĆ,V.(2004): Fenotipska varijabilnost proizvodnih i reproduktivnih osobina bikovskih majki simentalske rase. Magistarska teza. Poljoprivredni fakultet, Beograd.

ROMČEVIĆ, LJ. (1999): Simentalska goveda u Srbiji. Beograd. 